\title{
Projections and Objectives
}

\section{1 \\ Projections for 2025 and 2050}

Based on the population projections made by the Jordanian, Palestinian and Israeli Departments of Statistics, an assessment has been made of the total population in the valley in the years 2025 and 2050. This includes natural growth of the autonomous population to $0.92 \%$ in 2050 . In addition, this Master Plan assumes that in Jordan the high number of foreign inhabitants in the valley will gradually decline as a result of assumed improving economic conditions in their countries of origin, including Syria, Iraq and Egypt. Under this projection it is assumed that all Israeli settlements in the Palestinian part of the Jordan Valley will be removed, irrespective of security arrangements, and that the Independent Palestinian State created will see a growth towards an estimated 500,000 people living in the Palestinian section of the Jordan Valley by 2050. It assumes natural population growth under strong economic development conditions in Israel. These assumptions lead to a total projected population in 2050 of 1,048 Million people living in the Jordan Valley, from the southern tip of the Sea of Galilee to the northern edge of the Dead Sea as presented below.

The per capita water demands are expected to grow in Jordan and Palestine as a result of better economic circumstances, while in Israel per capita water demand will continue to decrease due to increased efficiencies. A domestic per capita water demand of $80 \mathrm{CM}$ is assumed for all residents of the valley, be they Palestinian, Jordanian and Israeli.

The total Domestic Water Demands within the Jordan Valley for 2050 are $99 \mathrm{MCM} / \mathrm{year}$. This has been calculated as the total population times their per capita water demands. Local industrial and commercial water demands are considered to be included in these total estimates. In addition $100 \mathrm{MCM} / \mathrm{year}$ are expected to be transferred from the valley to supply Amman and the Northern Jordanian Governorates within the framework of a water trade between Israel and Jordan. However this will likely require adjustments to the Sea of Galilee water balance.
The agricultural water demands in the Jordan Valley are about $553 \mathrm{MCM}$ in 2050. In this Master Plan it is assumed that the total agricultural water demands will not increase for Jordan and Israel, and that the Palestinian agricultural water demands will grow with $40 \mathrm{MCM} / \mathrm{year}$ to accommodate for the under developed status in 2010, and that the agricultural water currently consumed by the settlements in the Jordan Valley will also used by the Palestinians once the independent state has been established. See Tables 3.1, 3.2, 3.3, 3.4, 3.5 and 3.6. In addition, it is suggested that highly treated wastewater from Jordan (70 MCM/year) and Jerusalem/West Bank (50 MCM/year) will be diverted to the Jordan Valley for Agricultural purposes.

In this Master Plan it is assumed that the agricultural efficiencies will increase substantially, particular for Jordan and Palestine ensuring that with the available water resources higher financial returns will be realized.

The total amount of wastewater that will be generated in the valley directly relates to the domestic water consumption. In this Master Plan it is assumed that $80 \%$ of the total domestic water demands will return to the system as wastewater. Within this Master Plan interventions are proposed to treat and reuse the wastewater generated locally to the maximum extend. It is assumed that by 2050 again $80 \%$ of all generated wastewater in the valley (or $64 \%$ of all urban water supply, or about $63 \mathrm{MCM} / \mathrm{year}$ ) will be reused for agricultural purposes. In addition it is assumed that about 44.8 MCM/year of the total 100 MCM supplied to Amman and the Northern Governorates will return again to the Jordan Valley for agricultural reuse purposes. This figure is based on the assumptions that $80 \%$ of all supplied water is returned as wastewater, that $70 \%$ of this wastewater will be made available in Jordan Valley and $30 \%$ will remain in the high lands, and that $80 \%$ of the wastewater in the Jordan Valley can be reused on agricultural fields for reuse purposes. See Tables 3.1, 3.2, 3.3, 3.4, 3.5 and 3.6.

If fully reused for agricultural purposes, this water is sufficient to supply water to $30,000-50,000$ dunum of agricultural land. It is also suggested that highly treated 
Table 3.1 Projected population numbers

\begin{tabular}{|c|c|c|c|c|c|}
\hline \multicolumn{3}{|c|}{ Jordan LJR Population } & $\begin{array}{l}\text { Population } \\
2010\end{array}$ & \begin{tabular}{|l|}
2025 \\
$137.42 \%$ \\
\end{tabular} & $\begin{array}{l}2050 \\
240.00 \%\end{array}$ \\
\hline IMD 1 & \multicolumn{2}{|c|}{ North Shouneh } & 108943 & 140713 & 261463 \\
\hline JMD 2 & \multicolumn{2}{|c|}{ Deir Alla } & 67,925 & 93,345 & 163,020 \\
\hline JMD 3 & \multicolumn{2}{|c|}{ South Shouneh } & 70,294 & 96,600 & 168,706 \\
\hline \multirow[t]{3}{*}{ JMD 4} & \multicolumn{2}{|c|}{ Foreign population } & 247,000 & 200,000 & 150,000 \\
\hline & \multicolumn{2}{|c|}{$\begin{array}{l}\text { Total, incl foreign } \\
\text { population }\end{array}$} & 494,162 & 539,658 & 743,189 \\
\hline & \multicolumn{2}{|c|}{$\begin{array}{l}\text { Total jordanian } \\
\text { nationals }\end{array}$} & 247,162 & 339,658 & 593,189 \\
\hline \multirow{2}{*}{\multicolumn{2}{|c|}{ Israel LJR population }} & \multicolumn{2}{|c|}{ Population 2010} & 2025 & 2050 \\
\hline & & \multicolumn{2}{|c|}{ Growth } & $124.80 \%$ & $180.00 \%$ \\
\hline \multicolumn{2}{|c|}{ Emek Hayarden } & \multicolumn{2}{|c|}{11,000} & 13,728 & 19,800 \\
\hline \multicolumn{2}{|c|}{ Emek Hamaayanot } & \multicolumn{2}{|c|}{11,000} & 13,728 & 19,800 \\
\hline \multicolumn{2}{|c|}{ Beit She'an } & \multicolumn{2}{|c|}{17,000} & 21,216 & 30,600 \\
\hline \multicolumn{2}{|c|}{ Hagilboa } & \multicolumn{2}{|c|}{10,000} & 12,480 & 18,000 \\
\hline \multicolumn{2}{|c|}{ Total } & \multicolumn{2}{|c|}{49,000} & 61,152 & 88,200 \\
\hline West Ba & nk LJR populat & & $\begin{array}{l}\text { Population } \\
2010\end{array}$ & 2025 & 2050 \\
\hline & & & $\begin{array}{l}\text { Autonomous } \\
\text { growth }\end{array}$ & $140.47 \%$ & $195.27 \%$ \\
\hline Palestini & ans & & Immigration & $112.00 \%$ & $700.00 \%$ \\
\hline & & & & 62,736 & 392,098 \\
\hline PMD 1 & $\begin{array}{l}\text { Bardala Clust } \\
\text { MD }\end{array}$ & & 5,259 & 16,923 & 70,619 \\
\hline PMD 2 & $\begin{array}{l}\text { Al-Bassariya } \\
\text { Cluster MD }\end{array}$ & & 4,564 & 15,787 & 68,380 \\
\hline PMD 3 & $\begin{array}{l}\text { Al-Jiftlik Clus } \\
\text { MD }\end{array}$ & & 6,499 & 18,948 & 74,615 \\
\hline PMD 4 & $\begin{array}{l}\text { Fasayil Cluste } \\
\text { MD }\end{array}$ & & 1,157 & 10,223 & 57,401 \\
\hline PMD 5 & $\begin{array}{l}\text { Al-Auja Clus } \\
\text { MD }\end{array}$ & & 4,423 & 15,557 & 67,925 \\
\hline PMD 6 & Jericho MD & & 34,112 & 64,048 & 163,591 \\
\hline Subtotal & palestinian & & 56,014 & 141,485 & 502,531 \\
\hline Settleme & & & & & \\
\hline IMD 1 & Cluster North & MD & 1,425 & 0 & 0 \\
\hline IMD 2 & $\begin{array}{l}\text { Cluster Centr } \\
\text { MD }\end{array}$ & & 3,960 & 0 & 0 \\
\hline IMD 3 & Cluster South & MD & 860 & 0 & 0 \\
\hline Subtotal & Israeli Settlers & & 6,245 & 0 & 0 \\
\hline Total & & & 62,259 & 141,485 & 502,531 \\
\hline
\end{tabular}

wastewater from Jerusalem/West Bank (50 MCM/year) will be diverted to the Jordan Valley for Agricultural purposes.

In terms of solid waste generation, this Master Plan assumes that the per capita waste generation will increase from $400 \mathrm{~kg}$ per person today to $475 \mathrm{~kg}$ in 2025 and to $600 \mathrm{~kg}$ per person per day in 2050. These assumptions are based on expected economic growth and related growing
Table 3.2 Projected per capita urban water demands

\begin{tabular}{|c|c|c|c|c|}
\hline \multirow{2}{*}{\multicolumn{2}{|c|}{$\begin{array}{l}\text { Per capita water demands in } \\
\text { Jordan }\end{array}$}} & \multirow[t]{2}{*}{2010} & \multirow{2}{*}{$\begin{array}{l}2025 \\
117.00 \%\end{array}$} & 2050 \\
\hline & & & & $133.33 \%$ \\
\hline JMD 1 & North Shouneh & 60 & 70 & 80 \\
\hline JMD 2 & Deir Alla & 60 & 70 & 80 \\
\hline JMD 3 & South Shouneh & 60 & 70 & 80 \\
\hline JMD 4 & Foreign population & 30 & 30 & 30 \\
\hline \multirow{2}{*}{\multicolumn{2}{|c|}{$\begin{array}{l}\text { Per capita water demands in } \\
\text { Israel }\end{array}$}} & \multirow[t]{2}{*}{2010} & 2025 & 2050 \\
\hline & & & $94.44 \%$ & $88.89 \%$ \\
\hline \multicolumn{2}{|c|}{ All water users } & 90 & 85 & 80 \\
\hline \multirow{2}{*}{\multicolumn{2}{|c|}{$\begin{array}{l}\text { Per capita water demands in } \\
\text { Palestine }\end{array}$}} & \multirow[t]{2}{*}{2010} & 2025 & 2050 \\
\hline & & & $116.67 \%$ & $133.33 \%$ \\
\hline \multicolumn{2}{|c|}{ Palestinians } & 60 & 70 & 80 \\
\hline \multicolumn{2}{|c|}{ Settlements } & 90 & 0 & 0 \\
\hline
\end{tabular}

Table 3.3 Projected urban water demands

\begin{tabular}{|c|c|c|c|c|c|}
\hline \multicolumn{2}{|c|}{$\begin{array}{l}\text { Total domestic water demands } \\
\text { Jordan (CM/year) }\end{array}$} & \multicolumn{2}{|c|}{2010} & 2025 & \multirow{2}{*}{$\begin{array}{l}2050 \\
20,917.056\end{array}$} \\
\hline JMD 1 & North Shouneh & \multicolumn{2}{|c|}{$6,536.580$} & $10,509.846$ & \\
\hline JMD 2 & Deir Alla & \multicolumn{2}{|c|}{$4,075.500$} & $6,552.796$ & $13,041.600$ \\
\hline JMD 3 & South Shouneh & \multicolumn{2}{|c|}{$4,217.640$} & $6,781.336$ & $13,496.448$ \\
\hline JMD 4 & Foreign population & \multicolumn{2}{|c|}{$7,410.000$} & $6,000.000$ & $4,500.000$ \\
\hline JMD 5 & $\begin{array}{l}\text { From LJR Basin to } \\
\text { Amman (and northern } \\
\text { Governorates) }\end{array}$ & \multicolumn{2}{|c|}{$60,000.000$} & $80,000.000$ & $100,000.000$ \\
\hline \multicolumn{2}{|l|}{ Total } & \multicolumn{2}{|c|}{$82,239.720$} & $109,843.979$ & $151,955.104$ \\
\hline \multicolumn{3}{|c|}{$\begin{array}{l}\text { Total domestic water demands Israel } \\
\text { (CM/year) }\end{array}$} & 2010 & 2025 & 2050 \\
\hline \multicolumn{2}{|c|}{ Emek Hayarden } & \multicolumn{2}{|r|}{990,000} & $1,166.880$ & $1,584.000$ \\
\hline \multicolumn{3}{|c|}{ Emek Hamaayanot } & 990,000 & $1,166.880$ & $1,584.000$ \\
\hline \multicolumn{3}{|c|}{ Beit She'an } & \multirow{2}{*}{$\begin{array}{l}1,530.000 \\
900.000\end{array}$} & $1,803.360$ & $2,448.000$ \\
\hline \multicolumn{3}{|c|}{ Hag i I boa } & & $1,060.800$ & $1,440.000$ \\
\hline \multicolumn{2}{|c|}{ Total } & \multicolumn{2}{|r|}{$4,410.000$} & $5,197.920$ & $7,056.000$ \\
\hline \multicolumn{2}{|c|}{$\begin{array}{l}\text { Total domestic water demands } \\
\text { Palestine (CM/year) }\end{array}$} & & 2010 & 2025 & 2050 \\
\hline \multicolumn{6}{|c|}{ Palestinians } \\
\hline PMD 1 & \multicolumn{2}{|l|}{ Bardala Cluster MD } & 315.540 & $1,099.962$ & $5,649.520$ \\
\hline PMD 2 & \multicolumn{2}{|l|}{ Al-Bassariya-Cluster MD } & 273,840 & $1,026.155$ & $5,470.400$ \\
\hline PMD 3 & \multicolumn{2}{|l|}{ Al-Jiftlik Cluster MD } & 389,940 & $1,231.587$ & $5,969.200$ \\
\hline PMD 4 & Fasayil Cluster MD & & 69,420 & 664,462 & $4,592.080$ \\
\hline PMD 5 & Al-Auja Cluster MD & & 265,380 & $1,011.205$ & $5,434.000$ \\
\hline PMD 6 & Jericho MD & & $2,046.720$ & $4,163.119$ & $13,087.280$ \\
\hline Subtotal & palestinian & & $3,360.840$ & $9,196.490$ & $40,202.480$ \\
\hline Settleme & & & & & \\
\hline IMD 1 & Cluster north MD & & 128,250 & 0 & 0 \\
\hline IMD 2 & Cluster central MD & & 356,400 & 0 & 0 \\
\hline IMD 3 & Cluster south MD & & 77,400 & 0 & 0 \\
\hline Subtotal & Israeli settlers & & 562,050 & 0 & 0 \\
\hline Total & & & $3,922.890$ & $9,196.490$ & $40,202.480$ \\
\hline
\end{tabular}


Table 3.4 Total agricultural water demands (including brackish water)

\begin{tabular}{|c|c|c|c|c|}
\hline \multirow{2}{*}{\multicolumn{2}{|c|}{$\begin{array}{l}\text { Total agricultural water } \\
\text { demands Jordan }\end{array}$}} & \multirow{3}{*}{$\begin{array}{l}2010 \\
103,596.865\end{array}$} & \multicolumn{2}{|l|}{ CM/year } \\
\hline & & & \multirow{2}{*}{$\begin{array}{l}2025 \\
103,596.865\end{array}$} & \multirow{2}{*}{$\begin{array}{l}2050 \\
103,596.865\end{array}$} \\
\hline JAD1-4 & $\begin{array}{l}\text { Zone } 1 \\
(115,300 \\
\text { dunum) }\end{array}$ & & & \\
\hline JAD5-8 & $\begin{array}{l}\text { Zone } 2 \\
(74,959 \\
\text { dunum) }\end{array}$ & $107,169.170$ & $107,169.170$ & $107,169.170$ \\
\hline JAD9-16 & $\begin{array}{l}\text { Zone } 3 \\
(120,835 \\
\text { dunum) }\end{array}$ & $65,492.271$ & $65,492.271$ & $65,492.271$ \\
\hline \multicolumn{2}{|l|}{ Total } & $276,258.306$ & $276,258.306$ & $276,258.306$ \\
\hline \multirow{2}{*}{\multicolumn{2}{|c|}{$\begin{array}{l}\text { Total agricultural water } \\
\text { demands Israel }\end{array}$}} & 2010 & \multicolumn{2}{|l|}{ CM/year } \\
\hline & & & 2025 & 2050 \\
\hline \multicolumn{2}{|c|}{ Jordan Valley WA } & $21,237.000$ & $21,237.000$ & $21,237.000$ \\
\hline \multicolumn{2}{|c|}{ Afikey Main WA } & $52,015.000$ & $52,015.000$ & $52,015.000$ \\
\hline \multicolumn{2}{|c|}{ Harod WA } & $22,000.000$ & $22,000.000$ & $22,000.000$ \\
\hline \multicolumn{2}{|c|}{ Fish ponds } & $56,400.000$ & $56,400.000$ & $56,400.000$ \\
\hline \multicolumn{2}{|l|}{ Total } & $151,652.000$ & $151,652.000$ & $151,652.000$ \\
\hline \multirow{2}{*}{\multicolumn{2}{|c|}{$\begin{array}{l}\text { Total agricultural water } \\
\text { demands Palestine }\end{array}$}} & 2010 & \multicolumn{2}{|l|}{$\mathrm{CM} /$ year } \\
\hline & & & 2025 & 2050 \\
\hline
\end{tabular}

\section{Palestinians}

\begin{tabular}{l|l|r|r|r}
\hline PAD 1 & Bardala Cluster & $10,558.755$ & $13,658.850$ & $13,658.850$ \\
\hline PAD 2 & $\begin{array}{l}\text { Al-Bassariya } \\
\text { Cluster }\end{array}$ & $5,240.855$ & $14,396.297$ & $14,396.297$ \\
\hline PAD 3 & Al-Jiftlik Cluster & $5,400.437$ & $24,555.879$ & $24,555.879$ \\
\hline PAD 4 & Fasayil Cluster & $1,173.919$ & $20,329.361$ & $20,329.361$ \\
\hline PAD 5 & AI-AuiA Cluster & $3,991.597$ & $23,147.039$ & $23,147.039$ \\
\hline PAD 6 & Jericho & $11,082.381$ & $29,083.044$ & $29,083.044$ \\
\hline
\end{tabular}

Settlements

\begin{tabular}{l|l|r|c|c}
\hline IAD 1 & Cluster north AD & $3,100.095$ & 0 & 0 \\
\hline IAD 2 & $\begin{array}{l}\text { Cluster central } \\
\text { AD }\end{array}$ & $36,621.768$ & 0 & 0 \\
\hline IAD 3 & Cluster south AD & $8,000.662$ & 0 & 0 \\
\hline Total & & $85,170.469$ & $125,170.470$ & $125,170.470$ \\
\hline
\end{tabular}

waste generation per capita similar to Western European averages. This Master Plan proposes interventions that will process and treat these waste streams in a fully sanitary fashion, based on a maximum of reuse and recycling, and including the use of sanitary landfills.

Assuming that in 2050 about $50 \%$ of the domestic waste stream consists of organic waste, this leads to about 400,000 tons of organic waste being generated in 2050 in the valley. Regional experience shows that a maximum of $50 \%$ of the organic waste stream could be physically separated, leading to 200,000 tons of organic waste being separated in 2050. If fully processed into compost, this leads to a compost production in 2050 of 200,000 tons/year, which is sufficient to
Table 3.5 Wastewater reuse projections

\begin{tabular}{|c|c|c|c|c|c|}
\hline \multirow{3}{*}{\multicolumn{3}{|c|}{$\begin{array}{l}\text { Jordan Valley (Jordan) wastewater } \\
\text { reuse for urb agricultural reuse } \\
\text { targets }\end{array}$}} & \multirow[t]{2}{*}{2010} & \multicolumn{2}{|l|}{ CM/year } \\
\hline & & & & 2025 & 2050 \\
\hline & & & $0 \%$ & $50 \%$ & $80 \%$ \\
\hline JMD 1 & \multicolumn{2}{|l|}{ North Shouneh } & 0 & $4,203.938$ & $13,386.916$ \\
\hline JMD 2 & \multicolumn{2}{|l|}{ Deir Alla } & 0 & $2,621.119$ & $8,346.624$ \\
\hline JMD 3 & \multicolumn{2}{|l|}{ South Shouneh } & 0 & $2,712.535$ & $8,637.727$ \\
\hline JMD 4 & \multicolumn{2}{|c|}{ Foreign population } & 0 & $2,400.000$ & $2,880.000$ \\
\hline JMD 5 & \multicolumn{2}{|c|}{$\begin{array}{l}\text { Return flow to LJRB from } \\
\text { Amman/Northern } \\
\text { Governorates }\end{array}$} & 0 & $22,400.000$ & $44,800.000$ \\
\hline \multicolumn{3}{|l|}{ Total } & 0 & $34,337.591$ & $78,051.267$ \\
\hline \multirow{3}{*}{\multicolumn{2}{|c|}{$\begin{array}{l}\text { Jordan Valley (Israel) } \\
\text { Local wastewater reuse for } \\
\text { agricultural reuse targets }\end{array}$}} & \multirow{2}{*}{\multicolumn{2}{|c|}{2010}} & \multicolumn{2}{|l|}{ CM/year } \\
\hline & & & & 2025 & 2050 \\
\hline & & \multicolumn{2}{|l|}{$80 \%$} & $80 \%$ & $80 \%$ \\
\hline \multicolumn{2}{|c|}{ Emek Hayarden } & \multicolumn{2}{|c|}{633,600} & 746,803 & $1,013.760$ \\
\hline \multicolumn{2}{|c|}{ Emek Hamaayanot } & \multicolumn{2}{|c|}{633,600} & 746,803 & $1,013.760$ \\
\hline \multicolumn{2}{|c|}{ Beit She'an } & \multicolumn{2}{|c|}{979,200} & $1,154.150$ & $1,566.720$ \\
\hline \multicolumn{2}{|c|}{ Haqilboa } & \multicolumn{2}{|c|}{576,000} & 678,912 & 921,600 \\
\hline \multicolumn{2}{|c|}{ Total } & \multicolumn{2}{|c|}{$2,822.400$} & $3,326.669$ & $4,515.840$ \\
\hline \multirow{3}{*}{\multicolumn{3}{|c|}{$\begin{array}{l}\text { Jordan Valley (Palestine) local } \\
\text { wastewater reuse for agricultural } \\
\text { reuse targets }\end{array}$}} & 2010 & \multicolumn{2}{|l|}{$\mathrm{CM} /$ year } \\
\hline & & & & 2025 & 2050 \\
\hline & & & $0 \%$ & $50 \%$ & $80 \%$ \\
\hline \multicolumn{6}{|c|}{ Palestinians } \\
\hline PMD 1 & \multicolumn{2}{|c|}{ Bardala Cluster MD } & 0 & 473,830 & $3,615.693$ \\
\hline PMD 2 & \multicolumn{2}{|c|}{ Al-Bassariya Cluster MD } & 0 & 442,036 & $3,501.056$ \\
\hline PMD 3 & Al-Jiftlik Cluster & MD & 0 & 530,530 & $3,820.288$ \\
\hline PMD 4 & Fasayil Cluster M & & 0 & 286,230 & $2,938.931$ \\
\hline PMD 5 & Al-Auja Cluster $\mathrm{N}$ & & 0 & 435,596 & $3,477.760$ \\
\hline PMD 6 & Jericho MD & & 0 & $1,793.344$ & $8,375.859$ \\
\hline Subtotal & palestinian & & 0 & $3,961.566$ & $25,729.587$ \\
\hline Settleme & & & & & \\
\hline IMD 1 & Cluster north MD & & 0 & 0 & 0 \\
\hline IMD 2 & Cluster central $\mathrm{M}$ & & 0 & 0 & 0 \\
\hline IMD 3 & Cluster south MD & & 0 & 0 & 0 \\
\hline Subtotal & Israeli settlers & & 0 & 0 & 0 \\
\hline Total & & & 0 & $3,961.566$ & $25,729.587$ \\
\hline
\end{tabular}

support about 120,000-200,000 dunum of agricultural land in the Jordan Valley.

The remaining waste fraction is to be treated $(50 \%)$ and recycled separately $(50 \%)$. Eventually this might be done through incineration or sanitary landfilling. Assuming that sanitary landfilling is the preferred treatment technology in the Jordan Valley, this leads to a total required landfilling capacity until 2050 of about 7 MCM of waste. Assuming average sanitary landfills with a height of 15 meters, this will require sanitary landfill surface area of about 500 dunum until 2050, excluding related infrastructure. 
Table 3.6 Solid waste generation projections

\begin{tabular}{|c|c|c|c|c|c|}
\hline \multirow{2}{*}{\multicolumn{2}{|c|}{$\begin{array}{l}\text { Jordan total waste } \\
\text { generation }\end{array}$}} & \multirow{2}{*}{\multicolumn{2}{|c|}{2010}} & \multicolumn{2}{|l|}{ Tons/year } \\
\hline & & & & \multirow{2}{*}{$\begin{array}{l}2025 \\
71,114\end{array}$} & \multirow{2}{*}{$\begin{array}{l}2050 \\
156,878\end{array}$} \\
\hline JMD 1 & North Shouneh & \multicolumn{2}{|c|}{43,577} & & \\
\hline JMD 2 & Deir Alla & \multicolumn{2}{|c|}{27,170} & 44,339 & 97,812 \\
\hline JMD 3 & South Shouneh & \multicolumn{2}{|c|}{28,118} & 45,885 & 101,223 \\
\hline \multicolumn{2}{|c|}{ Foreiqn population } & 98,8 & & 107,932 & 148,638 \\
\hline \multicolumn{2}{|c|}{ Total } & \multicolumn{2}{|c|}{197,697} & 269,269 & 504,551 \\
\hline \multirow{2}{*}{\multicolumn{2}{|c|}{ Palestine total waste generation }} & & \multirow[t]{2}{*}{2010} & \multicolumn{2}{|c|}{ Tons/year } \\
\hline & & & & 2025 & 2050 \\
\hline \multicolumn{6}{|c|}{ Palestinians } \\
\hline PMD 1 & \multicolumn{2}{|c|}{ Bardala Cluster MD } & 2,104 & 8,038 & 42,371 \\
\hline PMD 2 & \multicolumn{2}{|c|}{ Al-Bassariya Cluster MD } & 1,826 & 7,499 & 41,028 \\
\hline PMD 3 & \multicolumn{2}{|l|}{ Al-Jiftlik Cluster MD } & 2,600 & 9,000 & 44,769 \\
\hline PMD 4 & \multicolumn{2}{|l|}{ Fasayil Cluster MD } & 463 & 4,856 & 34,441 \\
\hline PMD 5 & \multicolumn{2}{|l|}{ Al-Auja Cluster MD } & 1,769 & 7,390 & 40,755 \\
\hline PMD 6 & \multicolumn{2}{|l|}{ Jericho MD } & 13,645 & 30,423 & 98,155 \\
\hline Subtotal & alestinian & & 22,406 & 67,205 & 301,519 \\
\hline Settleme & & & & & \\
\hline IMD 1 & Cluster north MD & & 855 & 0 & 0 \\
\hline IMD 2 & Cluster central MD & & 2,376 & 0 & 0 \\
\hline IMD 3 & Cluster south MD & & 516 & 0 & 0 \\
\hline Subtotal & raeli settlers & & 3,747 & 0 & 0 \\
\hline Total & & & 26,153 & 67,205 & 301,519 \\
\hline Israel tot & waste generation & 201 & & Tons/year & \\
\hline & & & & 2025 & 2050 \\
\hline Emek H & arden & 6,6 & 00 & 8,237 & 11,880 \\
\hline Emek H & haayanot & 6,6 & 00 & 8,237 & 11,880 \\
\hline Beit She & & 10,2 & & 12,730 & 18,360 \\
\hline Haqilboa & & 6,0 & 00 & 7,488 & 10,800 \\
\hline Total & & 29,4 & & 36,691 & 52,920 \\
\hline
\end{tabular}

\subsection{Strategic Planning Objectives}

\subsubsection{Introduction}

The key development challenge facing the NGO Master Plan is to strike the right developmental balance between a healthy economic developmental path for the valley and its people on the one hand, and a Jordan River with sufficient environmental flows to sustain a healthy eco-system on the other hand. To meet this objective there is a need to ensure that the river serves as a natural water conveyor and source for water supply for residents in and outside the valley. Creative solutions are therefore needed to provide sufficient water to supply the projected water requirements of both people and nature for 2025 and 2050. A prerequisite for peace and prosperity is the equitable sharing of water resources and public access to lands and the riverbanks for all riparian nationalities within an appropriate security framework.

Sustainable development is seen as a catalyst to peace building between Israel and Palestine and the deepening of cooperation between Jordan, Palestine and Israel as a means to achieve prosperity for their residents in the valley. A key condition for meeting this challenge is that Palestine is recognized as a full riparian to the Jordan River, entitled to have access to its fair share of water resources and sovereignty over its lands in the valley. This planning document makes no attempt to quantify equitable water rights from the Jordan River. All water allocations identified to each side are based on the needs of each side within the valley, with the assumption that the equitable water rights will be negotiated directly between the parties and might supply additional water resources to populations outside the valley. The terms Jordan Valley or Lower Part of the Jordan River Basin are interchangeable in this document.

In an earlier document researched and published by WEDO/EcoPeace Middle East, the target environmental flow for the river was identified as an estimated $400 \mathrm{MCM}$ per annum, with the target return flow of 220, 100 and 90 MCM identified for Israel, Syria and Jordan respectively. Given both the political situation in Syria and the lack of a Syrian team to be party to this NGO planning effort, the Master Plan does not attempt to determine in any detail from where and how the $100 \mathrm{MCM}$ requirements from Syria would flow into the river by 2050 , other than stating that it would lead to an additional 100 MCM flow from the Yarmouk River into the Jordan River. Therefore the 100 MCM annual contribution is not part of the WEAP model developed below and the model therefore speaks of a $300 \mathrm{MCM}$ annual flow to the Dead Sea.

The key strategic planning objectives that would promote sustainable development for the trans-boundary NGO Master Plan for the Jordan Valley have been identified below:

\subsubsection{Pollution Control and Sanitation}

The objective in terms of pollution control and sanitation is to eliminate all sources of environmental pollution in the Jordan Valley by 2025 . This requires full and adequate treatment and reuse of all wastewater flows in the valley and to embark on fully integrated solid waste management, including:

- (separate) waste collection;

- transportation;

- transfer;

- reuse and recycling of solid waste streams;

- selection, planning, design and construction of a sanitary landfill;

- closing of existing non-sanitary dump sites; 
- development of composting facilities;

- based on the polluter-pays-principle and progressive taxation for heavy consumers.

The situation today in terms of sanitation and wastewater treatment in Jordan and Palestine is poor. This impacts the public health, as well as the possibilities to use the water resources for economic development. The challenge is to reach a situation where generated wastewater is collection, treated and reused for agricultural purposes, or to introduce better functioning sanitation systems using substantially smaller amounts of water, such as vacuum removal of toilet effluents, or electric incinerating toilets. In any case, localized solutions are preferred, avoiding the use of extensive sewer systems throughout the Jordan Valley.

In terms of environmental management, the challenge will be to implement integrated environmental management systems throughout the valley, including monitoring, enforcement and public awareness on wastewater and solid waste management, also focused on non-pollution sources; groundwater protection; water quality management; soil quality and air quality. Land preservation, groundwater protection zoning and problems related to overgrazing are to be addressed adequately.

Sustainable environmental management also requires adequate tools, such as dedicated impact assessment tools and Strategic Environmental Assessments to test new policies and strategies related to the Jordan Valley. In addition, environmental management in the valley requires enhancing water and environmental awareness of all communities, schools and municipalities in the valley, and implementing environmental standards instance according to the ISO norms 14000 and 14001. In terms of agricultural environmental management the challenge is to assist farmers in applying sustainable agronomic practices, including regulation of the use of pesticides and fertilizers and promotion of environmentally sustainable substances. This will support farmers in reaching international agricultural export and import standards.

\subsubsection{Sustainable Water Management and River Rehabilitation}

In terms of sustainable water management the key challenge clearly is to overcoming the water scarcity related problems in the Jordan Valley. This means creating a sustainable water supply system that meets that current and future domestic and agricultural water demands; and at the same time preserves the water resources for future generations and for the environment. This requires an Integrated Water Resources Management regime for the whole (Lower) Jordan River, based on international co-operation among Israel, Jordan and
Palestine, supported with adequate water management tools (like WEAP) to ensure sustainable water supply and an increase of the base flow and rehabilitation of the ecological values of the Jordan River.

One of the related key challenges is to achieve full treatment of wastewater generated in the study area and full reuse for agricultural purposes. This will both reduce public health related risks and strengthen the agricultural sector. This requires development of a detailed technical and financial plan, including designs and tender documents, for full scale collection, treatment and reuse of the locally generated wastewater flows, including domestic, industrial (mainly olive oil wastewater in Jordan) and manure management.

Another key challenge is to restore the function of the Lower part of the Jordan River as a natural river and water conveyor in the valley for supply purposes, by keeping its flow as long as possible in the river. Rehabilitating the river will include actions in terms of realizing at least one minor flood (c.a. $20-50 \mathrm{~m}^{3} / \mathrm{s}$ )/year. In order to bring back the original habitats of the river, also the flow bed of the river are to be widened to about $50-70 \mathrm{~m}$ in the north and at least $30 \mathrm{~m}$ in the south, with flood plains on both sides.

The salinity of the Jordan River has a natural tendency to increase downstream due to natural drainage of brackish groundwater into the river, particularly in the southern part of the valley near the Dead Sea. The key challenge is to prevent any inflow of salt or brackish surface water into the river above the point where the river would still be fresh, i.e. above the confluent with Wadi Qelt. This implies bypassing the salt water from the Israeli Saline Water Carrier (SWC), the brackish water from the Israeli Fish Ponds, and the brine from the Abu Zeighan desalination plant to a new outflow located south of the river's confluent with Wadi Qelt, close to the Dead Sea. If this will be done, the river will be able to provide water of good quality for different user functions. In terms of chloride concentrations this means a maximum of $400 \mathrm{mg} / \mathrm{l}$ for drinking water purposes; $600 \mathrm{mg} / \mathrm{l}$ for fresh water irrigation; and $1500 \mathrm{mg} / \mathrm{l}$ for irrigation of date palms.

Another key challenge is to maintain total agricultural water demands at the same level as today, with the exception of Palestine which is currently heavily underdeveloped in terms of agriculture. To achieve a sustainable water balance within the valley and sufficient flows in the river it will furthermore be required that around 2020 Israel will largely cease pumping water to the extent possible out of the valley from the Sea of Galilee through the National Water Carrier (NWC), meanwhile maintaining its present agricultural water consumption within the valley; that the Sea of Galilee will be kept on a medium water level between the top and bottom red lines ("green line" as defined by the Israeli Water Authority); and that by 2050 Jordan will stop diverting water from the Yarmouk and other tributaries to the Kind Abdullah 
Canal (KAC) to the extent possible, and instead will use the Jordan River as main conveyor for its irrigation supply purposes. In addition, by 2050 Palestine would also use the Jordan River as its main water conveyor, meaning that the planned development of the West Ghor Canal will not be built.

These challenges require a series of related interventions, including adequate water data monitoring and modeling; promotion of water saving and water demand management measures in all sectors; provision of related training and institutional strengthening support services; improved regulations and enforcement on groundwater abstractions to stop groundwater depletion and salinization; and implementation of efficient water pricing policies and related enforcement.

In terms of water governance, the challenge will be to strengthen the authorities, including JVA, PWA, in their role as regulator of the water sector in the Jordan Valley. This includes skills with regard to water data collection and management; water resources planning; efficient operations of the water storage and supply system; and strengthening the co-operation with the local water user associations. It also includes monitoring, regulations and enforcement of surface water and groundwater abstractions; protection of sensitive shallow aquifers, efficient tariff policies, and monitoring reduction of agricultural pollution loads.

\subsubsection{Sustainable Agriculture}

Sustainable Agriculture Development is one of the most important pillars of the Jordan Valley Plan as it provides livelihood and prosperity for the whole people in the valley. The strategic agricultural objective for the study area is improving water use and irrigation efficiencies and economic outputs per unit of water used, and meanwhile stabilize, or even reduce the total water demands for the agricultural sector in the Jordan Valley. This will require adequate tariff policies on water used for irrigation, including enforcement, to stimulate more efficient use of water through for instance green house drip irrigation. These are challenges specifically relevant for Jordan and Palestine.

Greenhouses are a very effective manner to improve water efficiencies and economic outputs in the agricultural sector, using greenhouses reduce the production related risks, provide for better quality crops and provide wider options for crop diversification. Finally, evapotranspiration from greenhouses is substantially less than from open field agriculture (and it does not cause soil salinity). However, greenhouses decrease open spaces, with negative visual impacts to rural landscapes and to wildlife corridors. Hence, greenhouse development needs to be carefully planned and many farmers would require adequate and reliable micro-credits in order to invest in greenhouses.

Drip irrigation is another effective manner to improve water efficiencies in the open fields. The challenge is to set up sustainable drip irrigation systems in the Jordan Valley, including appropriate operations and maintenance and monitoring systems. This requires also financial facilities for farmers to invest, standardization of designs and manufacturing and provision of technical support services.

A related challenge is to maximize the reuse of treated wastewater, efficient use of pesticides and fertilizers, introduction or expansion of growing high yield crops, and improving extension services and post harvesting support to the farmers to enable them to create higher economic returns.

The main agricultural challenge in Israel is to address the negative environmental impacts associated with the fish farms. These farms consume substantial amounts of water, due to high evaporation rates, which may be as much as 1$2 \mathrm{~m}$ of water per year. In addition the ponds are flushed once or twice per year, releasing water into the Jordan River, which is polluted with excrements from the fishes, and anti-biotic medications that have to be added to the fish ponds. Due to the evaporation, the effluent is usually brackish as well. Consequently, discharging this wastewater into the environment has substantial impacts to surface water and groundwater quality. Mitigating these impacts require investments in wastewater treatment facilities, and converting the process to a closed system. Without resolving these issues the future of this industry in the valley must be in doubt, despite any ecological benefits that the fish farms present for bird migration and associated tourism related to bird watching. The master plan sees the need to ensure that those communities relying currently on the fish ponds as their main source of income enjoy stability and that they be supported in the effort to move to closed systems.

A related challenge will be to strengthen the Extension Services for the farmers in the Jordan Valley. These services might be provided through the existing water user associations. In terms of rural economics, an important challenge is to improve the post-harvesting and marketing potentials of the farmers in the Jordan Valley, including setting up product organizations, better information about markets (nationally and internationally) and related product requirements and creating better access to export markets, with particular focus on eco-friendly and sustainable production techniques, regional labeling and fair-trade related markets. 


\subsubsection{Jordan Valley Governance}

\subsubsection{Institutional Strengthening}

The institutional challenge will be to strengthen responsible land and water authorities, including JVA, WAJ and PWA, municipalities and related authorities in their role as authority and regulator of the Jordan Valley. Improvements are required in areas such as water data collection and management; water planning; water storage and distribution operations, including IT and wireless data transfer, economic and land use planning and related support services. This will also require improved coordination and cooperation between various stakeholders involved in water management, to enable to more efficient and beneficial water economy. The subsidiary principle is here recommended where decision making and empowerment should take place at the level of authority closest to the resident for the issue concerned. In Jordan and Palestine, this would result in considerable investment in municipal authorities.

\section{Advocacy and Local Community Empowerment}

Development of the Jordan Valley requires that local communities will fully participate in identifying their needs and in implementing the interventions for addressing these needs. This requires that local communities are educated and empowered; and that the general public awareness on the current problems and possible solutions in terms of sustainable development is raised. This requires support from local media as well as local governments and municipalities, as well as support from the responsible authorities.

\section{Social Responsibility}

Sustainable development and governance of the Jordan Valley shall also include social responsibilities, including fair payment of wages, inclusion of social security, safe and healthy working conditions, training of employees and equal gender opportunities.

\section{International Co-operation}

Maximizing the economic and environmental development perspectives in the Jordan Valley requires that trans-boundary co-operation will be strengthened, particularly among Jordan, Israel and Palestine. This may include preparing for a joint Jordan Valley Organization; updating the Jordanian-Israeli Water Agreements taking into account the increased water stress in Jordan and a new water division based on proportional distribution of water (percentages instead of fixed flows); joint restoration of the Lower part of the Jordan River; and development of joint economic initiatives. Within the framework of this Master Plan proposals have been elaborated to establish regional Steering Committees under each Strategic Objective, which can eventually be incorporated into this joint Jordan Valley Organization. In the (very) long run the challenge might be to work towards an integrated Jordan Basin Commission for all riparian countries, including Israel, Jordan, Palestine, Syria and Lebanon. In the interim a Jordan Valley Commission between Jordan, Palestine and Israel should be advanced.

\subsubsection{Ecological Rehabilitation}

One of the key challenges in the Jordan Valley is to restore the good ecological status of the Jordan Valley, and the role of the Jordan River as a strategic water conveyor (Green Infrastructure), in line with earlier recommendations of WEDO/EcoPeace's Environmental Flow Study. This also includes restoration of the flood plain and the ecological (flora, fauna) status of the river, based on environmental flows and good water quality; design and implementation of dedicated ecological restoration projects and eco-parks along the borders of the Jordan River; expansion of currently assigned nature reserves, based on important flora, fauna and bird areas, also in accordance with the Ramsar Convention; and design and develop dedicated nature recreational areas for the urban population.

\subsubsection{Sustainable Tourism and Cultural Heritage Development}

Development of the tourism sector and the cultural heritage in the Jordan Valley is a major challenge for saving the intrinsic cultural heritage values in the valley, including its typical geology and morphology, the history of salt industries along the northern shores of the Dead Sea; the ancient sugar mills, the pre-historic irrigation systems, the archeological settlement and land use patterns, the mud brick architecture, and the beautiful hiking trails and related panoramas over the Jordan Valley. Developing these potentials will boost the economy and create jobs in the area, but requites planning for investments in related sites and infrastructure, such as near Jericho, Pella, the Bakoura National Park, and Old Gesher and the Naharayim sites.

This Master Plan aims to provide a sustainable management for an integrated natural-cultural Heritage and tourism development plan. The first priority is to develop a conservation management plan for natural and cultural heritage resources in the Jordan Valley. This conservation and management plan should lead to a sustainable management institution for monitoring the implementation of this plan and the protection of the Jordan Valley. A window for 
cooperation with other equivalent institutions in the other countries who share the Jordan Valley should be opened for common issues relevant to the management of the Jordan Valley.

This Master Plan also aims to facilitate the creation and the growth of the tourism business environment. The creation of business opportunities for the tourism industry is a multi-dimensional activity that can be initiated by public funds for vision and planning, access, infrastructure, public services as well as incentives for investment. There are some major projects like attractions that can be initiated with public and private initiatives like museums and archaeological site development. Those major attractions will enable small businesses to grow around them.

Visitor's experience need to be upgrade in terms of understanding and enjoying the natural and cultural history of the Jordan valley. A great amount of research about the Jordan Valley exists about its formation, natural and cultural history, contemporary life and others. More research is needed in order to better understand the Jordan Valley, but it is important to pass knowledge with the necessary and adequate communication methods like site presentation, museums, guiding and so on. This includes upgrading the visitor experience and appreciating and enjoying the tourism hospitality. Upgrading the accommodation capacity, food and beverage, transportation, guiding, banking, communications, health services, as well as cultural exchange forums like festivals are of most importance to be provided in the right distance from the tourist trail.

The Jordan Valley shall be promoted as a unique destination. "One valley-three countries" can make the Jordan valley a unique destination with an interesting experience in the three countries. This promotion campaign cannot be neglected in the near future. Nevertheless, it is the responsibility of the tourism industry to promote the Jordan Valley and the Dead Sea as a destination in the context of the national tourism promotion of the region. The two directions will cause no contradiction as they will only create more access to different markets. In addition to the traditional tourism fairs and exhibitions and familiarization trips, using information and communication technology is proving to be an effective access to any destination.

Reaching these tourism development objectives require development of tourism trails around various themes including nature protection, faith based experiences and rural sceneries, and cross border tourism attractions and trails such as new access sites along the Jordan River, a free tourism area at the northern head of the Dead Sea between Jordan and Palestine; and the Jordan River Peace Park between Jordan and Israel. It may also include linking the Baptism Sites to other tourism sites and trails in the valley, and creating synergies and stronger economic development opportunities.
Finally, this will include development of hotels and strengthening urban and rural tourism accommodations, such as bed and breakfast, local restaurants, support of woman's center and community centers. Many of these investments are to be development and financed by the private sector, and will therefore depend on the tourism perspectives in the Jordan Valley. In developing tourism facilities, the challenge will also be to fulfill environmental standards and eco-labels, similar to the EU Ecolabel or the Green Globe Ecolabel, and may also include bio-climatic design practices and use of renewable building materials. Border crossings need to be eased, allowing for foot crossing rather than shuttle buses as presently required and visa and fee requirement should be reevaluated in order to promote regional cross border tourism.

\subsubsection{Sustainable Urban, Energy and Infrastructure Development}

To facilitate the anticipated population and economic growth in the Jordan Valley, it will be crucial to develop sufficient urban housing and infrastructure facilities in the valley, and meanwhile increase traffic safety and public transport capacities. This is specifically relevant for the new State of Palestine and for Jordan. This may include improvement of main north-south roads through the valley, develop bypass roads around major urban areas; advance traffic safety through traffic lights, lining and public signs; establish sidewalks and bicycle trails; prepare for urban planning and housing projects to accommodate the foreseen growing population and its welfare, and development of trans-boundary infrastructure facilities, such as opening up of the Damya Bridge and the King Abdullah Bridge over the Jordan River.

\section{Sustainable Economic Development}

In order to further boost sustainable economic development in the Jordan Valley and related living standards for its population, additional economic development and private sector initiatives have to be supported, including community development projects; agro-industry and tourism development and specific economic initiatives providing high outputs against low water requirements.

\section{Sustainable Energy}

Sustainable economic development also requires promotion of the use of renewable energy sources, such as biogas; waste-to-energy; small scale solar energy and wind energy potentials in the valley, as well as promoting sustainable energy co-operation in the region. The potentials to harness solar energy in the region are huge. Developing these potentials might lead a substantial level of independence 
from fossil energy sources both for Jordan and for Palestine. Linking this to vocational education and research facilities in the Jordan Valley will further boost regional co-operation and economic development. In addition, donor-subsidized solar energy generation can be promoted as a major vehicle for co-operation, sustainable development and peace in the region. See also the Water and Energy Nexus on the website of WEDO/EcoPeace.

Open Access This chapter is distributed under the terms of the Creative Commons Attribution 4.0 International License (http://creative commons.org/licenses/by/4.0/), which permits use, duplication, adaptation, distribution and reproduction in any medium or format, as long as you give appropriate credit to the original author(s) and the source, a link is provided to the Creative Commons license and any changes made are indicated.

The images or other third party material in this chapter are included in the work's Creative Commons license, unless indicated otherwise in the credit line; if such material is not included in the work's Creative Commons license and the respective action is not permitted by statutory regulation, users will need to obtain permission from the license holder to duplicate, adapt or reproduce the material. 